ionic protein. Applying the dye-technique, the $p \mathrm{H}_{\mathrm{I}}$ was found to be $5 \cdot 5$ for the chrome-collagen compounds obtained by tanning with the extremely basic perchlorates of chromium. Thus, no appreciable displacement of the original isoelectric point of the collagen occurred due to the non-ionic chrome fixation. The binding of chromium by the nonionic protein groups should not be expected to affect the location of the $p \mathrm{H}_{\mathrm{I}}$.

The results of the present investigations suggest that the keto-imide group of collagen is responsible for the irreversible binding of the nonionic chromium complex of extremely basic perchlorates of chromium. No definite information on the nature of the valency forces involved in the attachment of the chromium complexes to the $-\mathrm{CO} \cdot \mathrm{NH}-$ - link at several points has as yet been obtained, whether the binding takes place by co-ordination of the oxygen atom of the ketogroup on the chromium complexes, the formation of some type of hydrogen bond, or by ionization of the - NH - link, or by a combination of such reactions. Rabin $^{10}$ and Murphy and Martell ${ }^{11}$ have presented evidence that peptide oxygen rather than peptide nitrogen is involved in the reversible interaction of some metal ions with simple peptides. The findings of improved hydrothermal stability and the changed reactivity of the chromed collagen, as well as the ability of the non-ionic chromium complexes to precipitate gelatin are satisfactorily explained by a reaction involving co-ordination of the chromium atoms on the oxygen atom of the keto-group of the keto-imide link. The main feature, which is firmly established, is that the compounds formed represent a novel type of metal-protein compounds which may be of value for the location of uncompensated ketoimide links in proteins, for example, by modern optical methods.

A grant from Statens Tekniska Forskningsråd is gratefully acknowledged.

${ }^{1}$ Gurd, F. R. N., and Wilcox, P. E., "Advances in Protein Chemistry", $11,311(1956)$.

${ }^{2}$ Gustavson, K. H. " "Chemistry of Tanning Processes" “(Academic: Press, New York, 1956)

${ }^{3}$ Jander, G., and Scheele, W., Z. anorg. allg. Chem., 206, 24 (1932).

"Gustavson, K. H., "Chemistry and Reactivity of Collagen" (Academic Press, New York, 1956). ${ }^{5}$ Gustavson, K. H., Acta Chem. Scand., 8, 1298 (1954); 9, 1049 (1955);

${ }^{8}$ Davy, H., J. Royal Inst. of Great Britain, 1, 273 (1803).

7 Grassmann, W., Collegium, 530 (1937).

s Page, R. O., J. Int. Soc. Leather Trades' Chem., 26, 71 (1942), Danieisson, C. E., Svensk Kem. Tidskr., 60, 142 (1948),

- Gustavson, K. H., Svensk Kem. Tidskr., 66, 359 (1954).

${ }^{20}$ Rabin, B. R., T'rans. Farad. Soc., 52, 1130 (1956).

${ }^{11}$ Murphy, C. B., and Martell, A. E., J. Biol. Chem., 226, 37 (195i).

\title{
OBITUARIES
}

\section{Mr. R. W. Sloley}

The news of the death of Mr. R. W. Sloley, of Amersham, Bucks, on August 19 at the age of seventy-nine, has been received with sorrow by a large circle of friends and scholars. $\mathrm{He}_{e}$ took his degree at St. John's College, Cambridge, and he never lost contact with his University. After graduating, he joined the staff of Liverpool College, but during the First World War he went to the Department of Instrument Inspection of the Air Ministry, where he remained for the rest of his professional career. $\mathrm{He}$ speedily made his mark in this Department, and during the War spent some time stationed in France. When peace came, he continued his work at the Air Ministry depot at Kidbrooke, and during his service there he wrote a book on aircraft instruments which ran into several editions and is still in use.

At first he lived at Blackheath, but in the later 1920's he migrated to Amersham, where, while continuing to serve at Kidbrooke, he settled down for the rest of his life in company with his father and his sister, for he never married. Both these relatives died before him, and during the last years of his life he lived alone except for his books and his many friends, to whom he frequently extended hospitality. Early in 1939 he retired from the Air Ministry, and thereafter devoted himself to his many hobbies.

Sloley was a widely travelled man, and in his earlier years had visited South Africa and India, for he had connexions with both countries. His interests outside his regular work included music and the arts (he became vice-president of the Chiltern Arts Club during his residence in Amersham); also science, general archæology and Egyptology. In this last subject he was particularly interested; he studied the Ancient Egyptian language for a year or two at University College, London, but his real interest was in Egyptian mathematics and science, and more particularly in Egyptian astronomy and methods of measuring time, on which topics he was probably better informed than any English professional Egyptologist. In November 1930 he delivered to the Egypt Exploration Society an admirable lecture on primitive methods of measuring time which was afterwards published in Vol. 17 of The Journal of Egyptian Archoeology, and in 1942 he contributed the chapter on science to the volume, "The Legacy of Egypt", edited by the late Prof. S. R. K. Glanville. $\mathrm{He}$ also served for some years on the committee of the Egypt Exploration Society. He did a great deal of lecturing to schools and societies, and once in the days of 2LO broadcast a talk on "A Day in the Life of an Egyptian Schoolboy". His last contribution to Egyptian archæology was a brief note in Vol. 39 of the Journal of Egyptian Archoeology on radiocarbon dating as applied to Egyptian antiquities. His interest in ancient science, however, was not confined to Egypt, but extended also to Babvlonia, and even perhaps to India. Under his quiet manner lay an unusually wide culture, and he will be greatly missed by all who knew him. R. O. FAULKNER

\section{Prof. George Fegler}

AfTER a distinguished career in medical and biological research, George Fegler died in Cambridge on September 23 at the age of fifty-nine. In Poland, between the time that he received his medical degree (Warsaw, 1924) and the outbreak of the Second World War, he held a number of important research and teaching posts, and in 1939 had just been elected to the chair of physiology at Vilna when he was recalled to the Army. Afterwards he worked in Edinburgh, where, during 194I-46, he was professor of physiology in the Polish Medical School and took part in the war research programme of the University 